\title{
Historical Data Type
}

National Cancer Institute

\section{Source}

National Cancer Institute. Historical Data Type. NCI Thesaurus. Code C95663.

A data type comprised of information concerning the historical aspects of a particular value. 